\author{
한우 암소에서 도체형질과 도체가격간의 상관관계 \\ 김대중 $^{1} \cdot$ 이창우 $^{2} \cdot$ 이채영 $^{3} \cdot$ 김종복 $^{1 *}$ \\ ${ }^{1}$ 강원대학교 동물생명과학대학 동물자원과학과, ${ }^{2}$ 강원도 축산기술연구센터, ${ }^{3}$ 숭실대학교 자연과학대학 생명정보학과
}

\title{
The Influence of Carcass Traits on Carcass Price in Mature Hanwoo Cow
}

\author{
Dae Jung Kim${ }^{1}$, Chang Woo Lee ${ }^{2}$, Chae Young Lee ${ }^{3}$ and Jong Bok Kim ${ }^{1} *$ \\ ${ }^{1}$ Department of Animal Resource Science, College of Animal Life Science, Kangwon National University, \\ ${ }^{2}$ Research Center for Livestock Technology, Gangwon-do, \\ ${ }^{3}$ Department of Bioinfomatics \& Life-Science, College of Natural Science, Soongsil University
}

\begin{abstract}
We investigated the influence of carcass traits on carcass price for Hanwoo cow using multiple regression and path analyses. Data for carcass traits and price were collected on mature Hanwoo cow raised in private farms in Kangwon province that were slaughtered in 2008. A total of 96 animals with the average slaughter age of 51 months were used in the current study. Of the carcass traits studied, marbling score (MAR), dressing percentage (DP), and eye-muscle area (EMA) showed moderate and positive correlations with auction price (AP), while correlation coefficients of meat yield index (MINDEX) with AP were low or even negligible. In multiple regression analyses of $\mathrm{AP}$ and carcass price $(\mathrm{CP})$ on cold carcass weight (CWT), back fat thickness (BFT), EMA, MAR, and DP, estimates of $\mathrm{R}^{2}$ were 69.86 and $85.43 \%$, respectively. Partial regression coefficients for CWT, BFT, EMA, MAR and DP were $-0.028,-0.106,0.107,0.814$, and 0.075 in the equation of AP and $0.561,-0.060,0.083,0.590$, and 0.051 in the equation of CP. In path analyses, MAR's total contribution on the variation of AP was largest (0.667), and the total contributions of MAR and CWT on the variation of $\mathrm{CP}$ were 0.403 and 0.397 . The current study suggested that marbling was the most influential trait on the variation of auction price, and marbling and cold carcass weight were critical traits on the variation of carcass price.
\end{abstract}

(Key words : Carcass traits, Carcass price, Multiple regression, Path analyses)

\section{서 론}

한우 번식용 큰 암소의 소고기 공급원으로서의 역할은 두 가지로 구분할 수 있다. 하나는 암소가 생산한 송아지가 비육되어 소고기 로 공급되는 간접적인 역할이고 또 하나는 암소 자체가 번식우로서 의 역할이 종료된 후 도축되어 소고기로 공급되는 직접적인 역할이 다. 물론 일생동안 많은 송아지를 생산한다는 점을 감안하면 암소 에서 쇠고기 공급의 간접적인 역할이 더 중요하겠지만 현재 우리나 라에서 사육되고 있는 큰 암소의 사육두수를 고려할 때 직접적인 쇠고기 공급원으로서의 역할 또한 무시하지 못할 정도의 중요성을 갖고 있다고 판단되는데, 정부에서 발표하고 있는 한우 사육통계를 보면 2009년도 9월 현재 한우 사육 총 두수는 2488천두이고 이중 약 $37 \%$ 에 달하는 927 천두가 2세 이상의 암소인 것으로 나타나고 있다(통계청 국가통계포털, 2009). 이 암소들은 대부분이 번식우로 사용되다가 번식우로서의 이용성이 떨어지게 되면 도축되어 소고기 로 국내에 공급될 것이다. 그러므로 국가 전체적으로 소고기 공급 전략을 수립하거나 번식우 사육농가의 수익성을 향상시키기 위해서
는 번식용으로 사육되는 암소들의 직접적인 소고기 공급원으로서의 역할에 관심을 가질 필요가 있다. 번식용 암소들의 소고기 공급원 으로서의 직접적인 역할을 높이기 위해서는 이들 성숙한 암소들에 대한 도체평가와 평가된 도체 형질과 도체 가격 간의 상관관계를 꾸준히 연구하고 이것을 통하여 한우 암소의 직접적인 소고기 공급 원으로서의 가치를 향상시키기 위한 방안을 연구할 필요가 있다.

본 연구에서는 큰 암소들의 도체 형질과 도체 판매가격을 조사하 고 이 조사된 자료를 이용하여 도체 형질을 원인 변수로 하고 도체 판매가격을 반응 변수로 하는 회귀분석 및 경로 분석을 통해 도체 판매가격에 미치는 각 도체 형질들의 영향력을 비교 하고자 실시하 였다.

\section{재료 및 방법}

1. 자 료

본 연구에 이용된 자료는 강원도 홍천지역에서 번식용으로 사육

\footnotetext{
* Corresponding author: Jong Bok Kim, Department of Animal Resource Science, College of Animal Life Sciences, Kangwon National University, Chuncheon 200-701, Korea. Tel: +82-33-250-8624, E-mail: jbkim@kangwon.ac.kr
} 
되다가 2008년도 6월부터 2008년도 12월 사이에 농협 서울공판장 에서 도축된 한우 성빈우 96두로부터 조사된 도체형질과 경락가격 등이었다. 도축된 암소들의 도축 시 일령은 도축 시까지 이표에 부 착되었던 바코드를 이용하여 한국종축개량협회에서 관리하고 있는 한우 등록 데이터베이스에서 개체별 생년월일을 조사한 후 도축까 지의 사육일수로 계산하였다. 이렇게 계산된 일령에 근거하여 암소 들을 다음과 같이 도축연령그룹으로 재분류하였다. 2세 그룹; 도축 시 일령이 720 일부터 1,080 일 미만인 암소, 3세 그룹; 1080 일 이 상-1440일 미만인 암소, 4세 그룹; 1440 일 이상-1800일 이상인 암소, 5세 그룹; 1800 일 이상인 암소. 도축된 암소 96 두의 도축 월 및 도축연령 그룹별 분포는 Table 1과 같았다.

분석에 이용된 조사항목은 도살시 생체중(live weight (LBW), $\mathrm{kg}$ ), 냉도체중 (carcass weight (CWT), $\mathrm{kg}$ ), 등지방두께 (backfat thickness (BFT), mm), 등심면적 (eye muscle area (EMA), $\mathrm{cm}^{2}$ ), 근내지방도 (marbling score (MAR), 점수), 육량지수 (meat yield index (MINDEX), 점수), 도체율 (dressing percentage (DP), \%), 경락단가 (auction price (AP), 원) 및 도체 판매대금 (carcass price (CP), 천원) 등 9개였는데, 이 중 $\mathrm{LBW}, \mathrm{CWT}, \mathrm{BFT}, \mathrm{EMA}$, $\mathrm{MAR}$ 및 $\mathrm{MINDEX}$ 는 정부에서 고시한 축산물등급판정기준(농림 부고시 제2007-40호, 2007.6.27)에 따라 조사하였으며, DP는 $\mathrm{LBW}$ 에 대한 $\mathrm{CWT}$ 의 백분비로 계산하였다. 그리고 $\mathrm{AP}$ 는 도체형 질에 대한 조사가 완료된 후 실시된 경매과정에서 결정된 해당 도 체의 $1 \mathrm{~kg}$ 당 경락가격을 원단위로 조사하였으며 $\mathrm{CP}$ 는 $\mathrm{AP}$ 를 $\mathrm{CWT}$ 에 곱하여 산출된 가격을 천원단위로 조사하였다.

설명의 편의를 위하여 조사된 형질 중 $\mathrm{LBW}, \mathrm{CWT}, \mathrm{BFT}$, $\mathrm{EMA}, \mathrm{MAR}$ 및 $\mathrm{DP}$ 를 도체형질로 그리고 $\mathrm{AP}$ 와 $\mathrm{CP}$ 를 가격변수로 분류하였다.

\section{2. 통계분석}

본 연구에서는 도체 형질들이 가격변수에 미치는 영향을 파악하

Table 1. Number of animals by slaughter month and age group

\begin{tabular}{rrrrrc}
\hline \multirow{2}{*}{ SM } & \multicolumn{5}{c}{ Age group } \\
\cline { 2 - 6 } & 2 & 3 & 4 & 5 & Total \\
\hline \hline 6 & - & 5 & 2 & 3 & 10 \\
7 & 4 & 8 & 1 & 4 & 17 \\
8 & 5 & 8 & 2 & 4 & 19 \\
9 & 1 & 3 & 3 & 1 & 8 \\
10 & 1 & 6 & 7 & 4 & 18 \\
11 & 2 & 3 & 1 & 4 & 10 \\
12 & 4 & 2 & 2 & 6 & 14 \\
\hline Total & 17 & 35 & 18 & 26 & 96 \\
\hline
\end{tabular}

* SM: slaughter month
기 위해 SAS Package (ver. 9.01, SAS Institute Inc., Cary, NC, USA.)를 이용하여 상관계수 추정, 다중회귀분석 및 경로분석 등을 실시했는데, 상관계수 추정과 회귀 분석은 아래(1)과 같은 선형모 형을 적용하여 분산분석을 실시한 다음 얻어진 잔차(residuals)를 이용하여 진행하였다. 잔차를 이용한 이유는 암소들의 도축월과 도 축시 연령이 같지 않기 때문에 발생하는 환경편차를 제거하기 위해 서였다.

$$
\mathrm{Y}_{\mathrm{ijk}}=\mu+\mathrm{SM}_{\mathrm{i}}+\mathrm{AGE}_{\mathrm{j}}+\mathrm{SM}_{\mathrm{i}} \times \mathrm{AGE}_{\mathrm{j}}+\mathrm{e}_{\mathrm{ijk}}
$$

여기서, $\mathrm{Y}_{\mathrm{ijk}}, \mu, \mathrm{SM}_{\mathrm{i}}, \mathrm{AGE}_{\mathrm{j}}, \mathrm{SM}_{\mathrm{i}} \times \mathrm{AGE}_{\mathrm{j},}, \mathrm{e}_{\mathrm{ijk}}$ 은 각각 개별관측 치, 전체 평균, $i$ 번째 도축월의 효과, $j$ 번째 도축연령그룹의 효과, $i$ 번째 도축월과 $j$ 번째 도축연령그룹 간의 상호작용 효과 및 임의 오 차 항이다.

잔차들의 상관계수는 SAS Package 중 PROC CORR을 이용하 여 pearson 상관계수를 구하였다.

가격변수들은 도체형질들에 의해 결정되므로 가격변수들이 도체 형질들에 의해 얼마나 영향을 받는가를 파악하기위해서 가격변수들 을 종속변수(반응변수)로 지정하고 도체형질들을 독립변수(원인변 수)로 적합 시킨 아래의 선형모형을 이용한 다중회귀분석(Multiple regression analysis)을 실시하였다.

$$
\begin{aligned}
& \mathrm{Y}=\mathrm{b}_{1} \mathrm{CWT}+\mathrm{b}_{2} \mathrm{BFT}+\mathrm{b}_{3} \mathrm{EMA}+\mathrm{b}_{4} \mathrm{MS}+\mathrm{b}_{5} \mathrm{DP}+\mathrm{e} \\
& \text { 여기서 } \mathrm{Y} \text { 는 종속변수로 이용된 } \mathrm{AP} \text { 또는 } \mathrm{CP} \text { 의 잔차, 그리고 }
\end{aligned}
$$
$\mathrm{CWT}, \mathrm{BFT}, \mathrm{EMA}, \mathrm{MS}$ 및 $\mathrm{DP}$ 는 각각 독립변수로 이용된 $\mathrm{CWT}$, $\mathrm{BFT}, \mathrm{EMA}, \mathrm{MS}$ 및 $\mathrm{DP}$ 의 잔차 (혹은 표준화시킨 잔차) 이고 $\mathrm{b}_{1}$, $\mathrm{b}_{2}, \mathrm{~b}_{3}, \mathrm{~b}_{4}, \mathrm{~b}_{5}$ 는 해당 형질들의 회귀계수이며 $\mathrm{e}$ 는 임의 오차이다.

다중회귀 모형을 적용해서 추정되는 특정 도체형질의 편 회귀계 수(Partial regression coefficient)는 모형에 적합 된 다른 도체형 질들은 변하지 않는 상태 하에서 특정 도체형질의 변화로 유발되는 가격변수의 변화량이 된다. 그리고 사전에 개별 관측치들을 해당형 질의 평균과 표준편차로 표준화시킨 후 다중회귀 분석을 실시하면 표준화 편 회귀계수(Standardized partial correlation coefficient)를 얻게 되는데, 특정 도체형질의 표준화 편 회귀 계수는 모 형에 적합된 다른 도체 형질들은 일정한 상태에서 그 도체형질의 변화에 의해 유발되는 가격변수의 변화량이 표준편차단위로 표현된 것이다. 그러므로 표준화 편 회귀계수는 개별 도체 형질들이 가격 변수에 미치는 영향력의 상대적 크기를 비교하는 기준으로 이용될 수 있다(Ibi 등, 2006; Kahi 등, 2007).

표준화 편 회귀계수는 경로계수 (Path coefficient)라는 용어로도 통용되고 있는데 Li (1967)와 Lynch and Walsh(1998) 등은 경로 계수와 독립변량들 간의 상관계수를 이용하여 독립변량들이 종속변 량에 미치는 영향력을 개별 독립형질별로 분할하는 과정을 설명한 바 있다. 본 연구에서는 가격변수에 미치는 도체형질들의 상대적 영향력을 파악하기 위하여 $\mathrm{Li}$ (1967)와 Lynch and Walsh (1998) 등이 제시한 방법에 따라 경로 분석을 실시하였다.

특정 도체 형질이 가격변수에 연결되는 경로는 그 도체 형질과 
가격변수 사이를 직접 연결하는 경로뿐만 아니라 모형에 적합된 다 른 도체 형질들과의 상관관계를 통해 연결되는 간접경로가 있다. 본 연구에서는 모형에 적합된 도체형질이 5 개이므로 각 도체 형질 마다 1 개의 직접경로와 4 개의 간접경로를 갖게 된다. 그러므로 특 정 도체 형질이 가격변수의 변이에 미치는 영향력은 직접경로를 통 해 미치는 영향력 (직접효과, Direct effect)과 4개의 간접경로를 통 한 미치는 영향력 (간접효과, Indirect effect)을 합해야 한다. 특정 도체 형질의 직접효과는 그 형질과 가격변수 사이의 경로계수를 자 승함으로서 구할 수 있으며, 간접효과는 간접경로 상에 있는 두 개 의 경로계수와 1 개의 상관계수를 구하므로서 얻어지게 된다. 즉 도 체 형질들이 가격변수들의 변이에 기여하는 정도는 다음과 같이 계 산할 수 있다.

$$
\mathrm{C}_{\mathrm{i}}=\mathrm{D}_{\mathrm{i}}+\sum \mathrm{IND}_{\mathrm{ij}}=\mathrm{PC}_{\mathrm{i}}^{2}+\sum \mathrm{PC}_{\mathrm{i}} \mathrm{CC}_{\mathrm{ij}} \mathrm{PC}_{\mathrm{j}}
$$

여기서, $\mathrm{C}_{\mathrm{i}}$ 는 개별 도체형질 $\mathrm{i}$ 의 기여도, $\mathrm{D}_{\mathrm{i}}$ 는 도체 형질 $\mathrm{i}$ 의 직 접효과, $\mathrm{IND}_{\mathrm{ij}}$ 는 형질 $\mathrm{j}$ 를 통한 형질 $\mathrm{i}$ 의 간접효과, $\mathrm{PC}_{\mathrm{i}}$ 와 $\mathrm{PC}_{\mathrm{j}}$ 는 형질 $\mathrm{i}$ 및 $\mathrm{j}$ 의 경로계수, 그리고 $\mathrm{CC}_{\mathrm{ij}}$ 는 형질 $\mathrm{i}$ 와 형질 $\mathrm{j}$ 의 상관계 수이다.

\section{결과 및 고찰}

본 연구에 이용된 한우 암소 96 두의 도축시 일령, 도체형질 및 가격변수들의 평균과 표준 편차 및 변이계수가 Table 2에 표시되 어 있다.

도축일령의 평균치는 1533.86 일 (약 51개월령) 이었으며 도축일 령이 제일 빠른 개체는 750 일 (25개월)이었고, 도축일령이 제일 늦
은 개체는 2881일 (약 96개월)이었다. 도체형질의 평균치는 LBW 가 $556.81 \mathrm{~kg}, \mathrm{CWT}$ 가 $319.24 \mathrm{~kg}, \mathrm{BFT}$ 가 $10.95 \mathrm{~mm}, \mathrm{EMA}$ 가 $78.08 \mathrm{~cm}^{2}$, 9단계로 구분하여 평가한 MAR가 3.92, 그리고 DP가 $57.19 \%$ 였으며, 가격변수로 분류된 $\mathrm{AP}$ 와 $\mathrm{CP}$ 의 평균치는 각각 12618원 및 4070천원이었다.

성숙한 한우 암소의 도체 형질 및 경락단가의 평균능력에 대한 최근의 연구보고로는 정 등 (2006)이 평균 산차 6.5산, 평균 연령 8.5 세인 한우 노산 암소를 대상으로 240 일간의 비육시험을 거친 후 대조구(처리구)의 평균능력이 LBW에서 $583.33(607.50) \mathrm{kg}$, CWT에서 $344.83(351.33) \mathrm{kg}, \quad \mathrm{BFT}$ 에서 $14.75(12.00) \mathrm{mm}$, $\mathrm{EMA}$ 에서 $77.17(85.56) \mathrm{cm}^{2}$, DP에서 $59.11(59.08) \%$ 였으며 시 험 직전에 측정한 체중은 492.25 (493.17) $\mathrm{kg}$ 이라고 보고하였고, 문 등 (2007)은 2000년부터 2005년 사이에 전국 101개 도축장에 서 도축된 자료를 분석한 결과 암소의 평균능력이 $\mathrm{CWT}, \mathrm{BFT}$, $\mathrm{EMA}$ 및 $\mathrm{MAR}$ 에서 각각 $307 \mathrm{~kg}, 10.53 \mathrm{~mm}, 73.92 \mathrm{~cm}^{2}$ 및 4.11 이었음을 보고한 바 있다.

외국에서 육우 암소를 대상으로 도체 형질의 평균능력을 조사한 결과를 살펴보면, Galli 등 (2008)은 헤어포드 종 암소 24두를 3세 그룹, 4 5세 그룹, 6 8세 그룹 및 12세 그룹으로 분류하여 140 일 간 방목초지에서 마무리 비육을 실시한 후 도축한 결과 비육종료 후 평균체중은 $468.1 \mathrm{~kg}$ 이었고 도살 후 측정한 $\mathrm{CWT}, \mathrm{BFT}$, $\mathrm{EMA}, \mathrm{MAR}$ 및 $\mathrm{DP}$ 의 평균치는 각각 $233.1 \mathrm{~kg}, 8.85 \mathrm{~mm}, 61.02$ $\mathrm{cm}^{2}, 3.05$ 및 50\%였음을 보고한 바 있고, Apple 등 (1999)은 83 두의 영국계통의 육우 암소 노폐우(연령 6 8세)에서 신체충실지수 에 따른 도체 형질들의 평균치는 CWT가 $175.2 ~ 335.7 \mathrm{~kg}, \mathrm{BFT}$ 가 $0.5 \sim 27.3 \mathrm{~mm}, \mathrm{DP}$ 가 $48.7 \sim 55.1 \%, \mathrm{EMA}$ 가 $41.0 \sim 78.4 \mathrm{~cm}^{2}$ 의

Table 2. Simple statistics for variables used in the study

\begin{tabular}{lrrrrr}
\hline Traits $^{1)}$ & \multicolumn{1}{c}{ Mean } & SE & CV & Min. & Max. \\
\hline \hline LBW (kg) & 556.81 & 6.96 & 12.25 & 424.00 & 751.00 \\
CWT (kg) & 319.24 & 4.77 & 14.64 & 230.00 & 453.00 \\
BFT (mm) & 10.95 & 0.48 & 43.30 & 4.00 & 24.00 \\
EMA (cm $\left.{ }^{2}\right)$ & 78.08 & 0.97 & 12.13 & 58.00 & 101.00 \\
MAR $^{\mathrm{a}}$ & 3.92 & 0.19 & 47.10 & 3.00 & 9.00 \\
DP (\%) & 57.19 & 0.22 & 3.78 & 52.09 & 63.54 \\
AP & 12618.92 & 274.24 & 21.29 & 7033.00 & 19599.00 \\
CP & 4070.35 & 121.75 & 29.31 & 1725.00 & 7320.18 \\
SAGE (d) & 1533.86 & 53.36 & 34.08 & 750.00 & 2881.00 \\
\hline
\end{tabular}

\footnotetext{
${ }^{1)} \mathrm{LBW}=$ live weight at slaughter; $\mathrm{CWT}=$ cold carcass weight; $\mathrm{BFT}=$ back fat thickness; EMA=eye-muscle area; $\mathrm{MAR}=\mathrm{marbling}$ score; $\mathrm{DP}=$ dressing percentage; $\mathrm{AP}=$ carcass price per $1 \mathrm{~kg}$ of carcass(unit; Korean Won $(\mathrm{KRW}), 1 \mathrm{US} \$ \fallingdotseq 1,200 \mathrm{KRW})$; $\mathrm{CP}=$ carcass total price per animal(unit; 1000KRW); SAGE=age at slaughter.

a evaluated on the Korean Beef Marbling Standard with scores 1 (poor) to 9 (best).
} 
범위로서 신체 충실 지수가 클수록 도체 형질의 평균치도 증가하는 경향이 있음을 보고한 바 있으며, Cranewell 등 (1996)은 지역 경 매시장에서 구입한 5세 이상인 영국계통 노산 암소 60 두에 대해서 즉시 도축했을 때의 평균능력은 DP가 $52.1 \%, \mathrm{CWT}$ 가 $238.2 \mathrm{~kg}$, $\mathrm{BFT}$ 가 $4.3 \mathrm{~mm}, \mathrm{EMA}$ 가 $66.8 \mathrm{~cm}^{2}$ 이었으나, 스테로이드 계통의 생 리활성물질을 투여한 후 56일간의 마무리 비육을 실시한 결과, DP 는 $54.0 \%, \mathrm{CWT}$ 는 $308.7 \mathrm{~kg}, \mathrm{BFT}$ 는 $1.10 \mathrm{~mm}$, 그리고 $\mathrm{EMA}$ 는 $80.0 \mathrm{~cm}^{2}$ 이었음을 보고한 바 있다.

변이계수 $(\mathrm{CV}$, coefficient of variation)는 다른 집단간에 변이 의 크기를 비교하는 수단으로, 또 동일 집단 내에서 측정단위가 다 른 두 형질 상이의 상대적 변이를 비교하는데 널리 이용되고 있다. 본 연구에서 $\mathrm{CWT}, \mathrm{BFT}, \mathrm{EMA}$ 및 $\mathrm{MAR}$ 의 변이계수는 각각 $14.64,43.30,12.13$ 및 47.10\%로서 $\mathrm{BFT}$ 와 $\mathrm{MAR}$ 의 $\mathrm{CV}$ 가 $\mathrm{CWT}$ 나 $\mathrm{EMA}$ 의 $\mathrm{CV}$ 보다 훨씬 컸다. $\mathrm{BFT}$ 와 $\mathrm{MAR}$ 의 $\mathrm{CV}$ 가 $\mathrm{CWT}$ 나 EMA의 $\mathrm{CV}$ 보다 훨씬 큰 결과는 한우에서 황 등 (2008) 이나 김 등 (2006), 그리고 일본 흑모화우에서 Oikawa 등 (2006), 일본 갈모화종에서 Kahi 등 (2007)도 보고한 바 있다. 그러나 유럽 계통의 소나 인도계통의 소에 대한 연구에서는 MAR의 CV가 본 연구에서 조사된 $47.10 \%$ 보다 작은 결과도 보고되고 있는데, Smith 등 (2007)은 브라만 거세우에서 $15.80 \%$ 로, Van Vleck 등 (2007)은 여러 육우 품종이 혼합된 집단에서 $15.69 \%$ 로, RiosUtrera (2005) 등은 Bos taurus 계통의 교잡종 및 순종 거세우 집 단에서 $14.27 \%$ 로 보고하였다. 이렇게 한국이나 일본에서 보고된 $\mathrm{MAR}$ 의 $\mathrm{CV}$ 와 유럽이나 인도계통의 소를 대상으로 한 연구에서 $\mathrm{MAR}$ 의 $\mathrm{CV}$ 가 차이가 나는 원인은 일차적으로 사양방법이나 유전 적 특성의 차이에 기인하는 것으로 생각할 수 있지만 또 다른 원인 으로는 MAR을 평가하는 기준이 다르기 때문에 나타날 수도 있음 을 생각해 볼 수 있다.

MAR을 평가하는데 있어 Smith 등 (2007)은 200부터 899까지
100 단위로 구분한 후 다시 각 단위 내에서 세분하는 평가방법을 이용하였으며, Van Vleck 등(2007)과 Rios-Utrera 등(2005)은 2 부터 10.9 까지 0.1 단위로 구분 평가한 반면 한국이나 일본에서는 1 부터 9 (한국), 또는 1 부터 12 까지 (일본) 1 단위로 구분하여 평가 하고 있다. 한편 Galli 등 (2008)은 헤어포드종 암소에서 도체형질 들의 변이계수를 조사한 결과 $\mathrm{CWT}$ 가 $10.5 \%, \mathrm{BFT}$ 가 $28.7 \%$, $\mathrm{EMA}$ 가 $12.2 \%, \mathrm{MAR}$ 이 $62.2 \%$ 로서 $\mathrm{MAR}$ 의 $\mathrm{CV}$ 가 상당히 큰 결 과를 보고한 바 있는데 이 연구에서는 MAR을 1 부터 7 까지 1 단위 로 구분 평가하였다.

Table 3에는 도체 형질 및 가격변수들 간의 상관계수가 표시되 어 있다.

$\mathrm{AP}$ 와 가장 큰 상관계수를 보인 도체 형질은 $\mathrm{MAR}(0.82)$ 였고, 그 다음은 $\mathrm{DP}(0.30)$ 와 $\operatorname{EMA}(0.22)$ 순이었다. 반면에 MINDEX는 $\mathrm{AP}$ 와의 상관계수가 -0.06 으로 매우 작았고 그 부호도 음수였는데 $\mathrm{MINDEX}$ 의 상관계수 -0.06 은 $\mathrm{MINDEX}$ 를 계산하는 산출공식에 포함되어 있는 형질인 $\mathrm{CWT}$ 나 $\mathrm{BFT}$ 그리고 $\mathrm{EMA}$ 보다 $\mathrm{AP}$ 와의 상관관계가 작은 것이다. 이것은 $\mathrm{MINDEX}$ 가 성숙한 암소 도체의 경락단가를 결정하는데 중요한 역할을 하지 못하고 있음을 의미한 다. $\mathrm{MINDEX}$ 와 $\mathrm{AP}$ 와의 상관계수가 작은 크기의 음수였던 본 연 구와는 달리 정 등 (2009)은 한우 거세우에서 MINDEX와 $\mathrm{AP}$ 간 에 비교적 큰 정의 상관계수 $(\mathrm{r}=0.16)$ 를 발표한 바 있다.

본 연구에서 추정된 $\mathrm{MAR}$ 과 $\mathrm{BFT}$ 사이의 정의 상관계수 $(\mathrm{r}=0.22)$ 는 근내지방도가 양호한 도체 일수록 등지방두께도 두꺼워 지는 경향을 보이고 있음을 시사하는 결과인데, 한우에 대한 최근 의 연구보고들은 대부분이 $\mathrm{MAR}$ 과 $\mathrm{BFT}$ 사이에 정의 상관관계가 있는 결과를 보고하고 있다(정 등, 2009; 문 등, 2007; 윤 등, 2002). 그러나 정의 상관관계를 갖고는 있으나 그 크기가 작아 통 계적으로 의미를 부여하기 어려운 결과도 보고되고 있는데, 김 등 (2006)이 한우 거세우 및 비거세우로 구성된 자료에서 0.03 , 박 과

Table 3. Residual correlation coefficients among traits

\begin{tabular}{|c|c|c|c|c|c|c|c|c|}
\hline Traits $^{1)}$ & CWT & BFT & EMA & MAR & MINDEX & DP & $\mathrm{AP}$ & $\mathrm{CP}$ \\
\hline LBW & $0.98 * *$ & $0.28 * *$ & $0.48 * *$ & 0.09 & $-0.40 * *$ & $0.52 * *$ & 0.11 & $0.65 * *$ \\
\hline CWT & & $0.30 * *$ & $0.53 * *$ & 0.14 & $-0.41 * *$ & $0.69 * *$ & 0.17 & $0.71 * *$ \\
\hline BFT & & & 0.11 & $0.22 *$ & $-0.94 * *$ & $0.25^{*}$ & 0.09 & $0.26^{*}$ \\
\hline EMA & & & & 0.12 & 0.08 & $0.49 * *$ & $0.22 *$ & $0.47 * *$ \\
\hline MAR & & & & & -0.19 & $0.27 * *$ & $0.82 * *$ & $0.68 * *$ \\
\hline MINDEX & & & & & & $-0.28 * *$ & -0.06 & $-0.30 * *$ \\
\hline DP & & & & & & & $0.30 * *$ & $0.62 * *$ \\
\hline AP & & & & & & & & $0.81 * *$ \\
\hline
\end{tabular}

* $\mathrm{p}<0.05 * * \mathrm{p}<0.01$

${ }^{1)} \mathrm{LBW}=$ live weight at slaughter; $\mathrm{CWT}=$ cold carcass weight; BFT=back fat thickness; EMA=eye-muscle area; $\mathrm{MAR}=$ marbling score; MINDEX $=$ meat yield index; $\mathrm{DP}=$ dressing percentage; $\mathrm{AP}=$ carcass price per $1 \mathrm{~kg}$ of carcass (unit; Korean Won $(\mathrm{KRW}), 1 \mathrm{US} \fallingdotseq 1,200$ $\mathrm{KRW}$ ); $\mathrm{CP}=$ carcass total price per animal (unit; 1000KRW); 
박 (2002)이 비거세 한우 수소에서 0.02 , 황 등이 한우 거세우에서 0.06, Oikawa 등 (2006)이 흑모화우에서 0.04 등으로 0에 가까운 정의 상관계수를 보고한 바 있다. 일반적으로 MAR과 BFT 사이 에 정의 상관관계가 있다는 것은 경제적으로 유리하지 못한 특성으 로 인식되고 있는데, 그것은 근내지방도를 향상시키기 위한 노력을 하게 되면 등지방도 함께 증가하는 요인이 되며 등지방두께가 두꺼 워지는 것은 불가식 지방의 함량을 높이므로서 불필요한 사료 지방 의 낭비가 되기 때문이다.

$\mathrm{CWT}$ 와 $\mathrm{EMA}$ 사이의 상관계수 0.53 은 도체중이 무거울수록 등 심면적도 넓어지는 경향을 보이고 있음을 시사하는 결과인데, 본 연구의 결과처럼 도체중과 등심면적 사이의 표현형상관계수가 양수 였던 결과로는 한우에서 정 등 (2009)의 0.44, 문 등 (2007)의 0.66 , 박과 박 (2002)의 0.67 , 윤 등 (2002)의 0.53 , 황 등 (2008) 의 0.53 등이 있으며 외국에서는 $\operatorname{Smith}(2007)$ 등이 브라만종 거 세우에서 $\mathrm{CWT}$ 와 EMA 사이의 표현형 상관계수가 0.39였음을 그 리고 Gresham 등 (1986)은 분만직후의 육우 암소 82두로부터 조 사한 도체중과 EMA 사이의 상관계수가 0.57 이었음을 보고한 바 있다.

Table 4에는 다중회귀 분석을 통해 추정된 형질별 편회귀계수 (Partial regression coefficient)와 표준화 편회귀계수(Standardized partial regression coefficient)를 표시하였다. 회귀모형에서 독립변 수로 포함된 도체형질은 $\mathrm{CWT}, \mathrm{BFT}, \mathrm{EMA}, \mathrm{MAR}$ 및 $\mathrm{DP}$ 등 5개 였고, 종속변수로는 $\mathrm{AP}$ 와 $\mathrm{CP}$ 가 교대로 이용되었다.

다중회귀모형의 $\mathrm{R}^{2}$ 값은 $\mathrm{AP}$ 에서 $69.86 \%$, 그리고 $\mathrm{CP}$ 에서 $85.43 \%$ 로 나타나 회귀 모형에 적합된 5 개의 도체형질들은 $\mathrm{AP}$ 의 변이 중 $69.86 \%$ 를 그리고 $\mathrm{CP}$ 의 변이 중 $85.43 \%$ 를 설명하고 있 음을 확인할 수 있었다.

$\mathrm{BFT}$ 와 $\mathrm{MAR}$ 에 대한 $\mathrm{AP}$ 의 편회귀 계수는 각각 -52.10 원과 1052.07 원으로 나타나 다른 도체 형질들은 변화하지 않고 일정한 수준을 유지한다는 전제하에서 $\mathrm{BFT}$ 가 $1 \mathrm{~mm}$ 증가함에 따라 $\mathrm{AP}$ 는 52.10 원씩 감소하는 경향을 보이며 MAR이 1 단위 증가함에 따라 $\mathrm{AP}$ 는 1052.07원씩 증가하는 경향을 보이는 것으로 나타났다. 한 편 $\mathrm{BFT}$ 에 대한 $\mathrm{CP}$ 의 회귀계수는 -13.01 로서 $\mathrm{BFT}$ 가 $1 \mathrm{~mm}$ 증가 함에 따른 $\mathrm{CP}$ 의 변화량은 약 13 천원씩 감소하는 것으로 나타났다. 본 연구와 같이 $\mathrm{BFT}$ 에 대한 회귀계수가 $\mathrm{AP}$ 와 $\mathrm{CP}$ 에서 모두 음수 로 추정된 것은 $\mathrm{Ibi}$ 등 (2006)이 일본의 흑모 화우를 대상으로 한 연구에서도 확인되고 있다.

표준화 편회귀계수의 절대값은 해당 독립변수들이 종속변수에 미 치는 영향력의 상대적 크기로 해석할 수 있는데 $\mathrm{AP}$ 의 경우 $\mathrm{MAR}$ 에서 0.814 로 제일 컸다. 이것은 다른 독립변량들이 변하지 않고 일정한 수준을 유지하는 상태에서 MAR이 1 표준편차 증가하면 이 원인으로 인해 $\mathrm{AP}$ 는 0.814 표준편차가 증가하는 것으로 해석 할 수 있다. MAR에 이어 그 다음으로 영향력이 컸던 도체 형질은 $\mathrm{BFT}$ 였으며 그 값은 -0.106 으로 나타나 BFT가 1 표준편차 증가 할수록 $\mathrm{AP}$ 는 0.106 표준편차 감소하고 있음을 알 수 있었다. 독립 변수로 모형에 적합된 5 개의 도체 형질 중에서 제일 영향력이 작
Table 4. Partial regression coefficients of carcass traits on carcass price

\begin{tabular}{cccc}
\hline $\begin{array}{c}\text { Price } \\
\text { variable }^{1)}\end{array}$ & $\begin{array}{c}\text { Carcass } \\
\text { traits }^{2}\end{array}$ & Partial $^{3)}$ & $\begin{array}{c}\text { Standardized } \\
\text { partial }^{4}\end{array}$ \\
\hline \hline AP & CWT & $-1.40 \pm 4.25$ & -0.028 \\
& BFT & $-52.10 \pm 30.58$ & -0.106 \\
& EMA & $26.93 \pm 17.70$ & 0.107 \\
& MAR & $1052.07 \pm 78.99$ & 0.814 \\
& DP & $87.78 \pm 97.16$ & 0.075 \\
CP & RWT & 0.6986 & 0.6986 \\
& BFT & $-13.01 \pm 9.36$ & -0.060 \\
& EMA & $9.17 \pm 5.42$ & 0.083 \\
& MAR & $335.89 \pm 24.17$ & 0.590 \\
& DP & $25.96 \pm 29.73$ & 0.051 \\
& $\mathrm{R}^{2}$ & 0.8543 & 0.8543 \\
\hline
\end{tabular}

$\mathrm{R}^{2}$; Coefficient of determination for the multiple regression model.

1) two price values, $\mathrm{AP}$ and $\mathrm{CP}$, were used successively as dependent variable.

2) five carcass traits, CWT, BFT, EMA MAR and DP, were fitted as independent variable.

3) partial regression coefficient.

4) standardized partial regression coefficient.

았던 형질은 $\mathrm{CWT}$ 로 표준화 편회귀계수의 크기가 -0.028 에 불과 하였다. 그 외 $\mathrm{AP}$ 에 대한 $\mathrm{EMA}$ 와 $\mathrm{DP}$ 의 표준화 편회귀계수는 각 각 0.107 과 0.075 였다. $\mathrm{CP}$ 의 경우에는 $\mathrm{CWT}$ 가 $0.561, \mathrm{BFT}$ 가 $-0.060, \mathrm{EMA}$ 가 0.083, MAR이 0.590 그리고 $\mathrm{DP}$ 가 0.051로서 $\mathrm{CP}$ 에 미치는 영향력은 $\mathrm{MAR}$ 이 제일 컸으며 그 다음으로 $\mathrm{CWT}$ 가 영향력이 큰 형질로 나타났다. 이에 반해 $\mathrm{BFT}, \mathrm{EMA}$ 및 $\mathrm{DP}$ 는 $\mathrm{CP}$ 에 미치는 영향력이 $\mathrm{CWT}$ 나 $\mathrm{MAR}$ 의 그것에 비해 현저히 작은 것으로 나타났다.

독립변수인 $\mathrm{CWT}, \mathrm{BFT}, \mathrm{EMA}, \mathrm{MS}$ 및 $\mathrm{DP}$ 와 종속변수인 $\mathrm{AP}$ 나 $\mathrm{CP}$ 와의 관계를 도체 형질들 간의 상관계수와 도체 형질에 대한 가 격변수들의 표준화 편 회귀계수 즉 경로계수를 이용하여 경로도 (Path diagram)로 표현하면 Fig. 1과 같다.

Fig. 1에서 단일방향 화살표 (single headed arrow)와 양방향 화 살표(double headed arrow)는 각각 경로계수와 상관계수를 의미 한다. 그림에서 각 도체 형질은 종속변량인 가격변수로 직접 연결 되는 경로와 다른 도체 형질들을 경유해서 종속변량으로 연결되는 간접경로가 있는데, 도체중의 예를 들면 직접경로 1 개와 $\mathrm{BFT}$, $\mathrm{EMA}, \mathrm{MAR}$, 및 $\mathrm{DP}$ 를 경유해서 종속변량으로 연결되는 4개의 간 접경로가 있다. 각 도체 형질로부터 종속변량에 연결되는 단일방향 화살표 (single headed arrow)상의 수자는 Table 4에 제시되었던 표준화 편회귀계수이며 양방향 화살표(double headed arrow) 상 
Table 5. Path contribution of carcass traits to carcass prices

\begin{tabular}{ccccccc}
\hline \multirow{4}{*}{ AP } & & CWT & BFT & EMA & MAR & DP \\
& CWT & 0.0008 & 0.0009 & -0.0016 & -0.0033 & -0.0015 \\
& BFT & 0.0009 & 0.0111 & -0.0012 & -0.0185 & -0.0020 \\
& EMA & -0.0016 & -0.0012 & 0.0114 & 0.0107 & 0.0039 \\
& MAR & -0.0033 & -0.0185 & 0.0107 & 0.6619 & 0.0165 \\
& DP & -0.0015 & -0.0020 & 0.0039 & 0.0165 & 0.0057 \\
\hline \multirow{2}{*}{ CP } & -0.0047 & -0.0097 & 0.0232 & 0.6672 & 0.0226 \\
& TC1 & 0.3145 & -0.0101 & 0.0247 & 0.0479 & 0.0195 \\
& CWT & -0.0101 & 0.0036 & -0.0005 & -0.0076 & -0.0008 \\
& BFT & 0.0247 & -0.0005 & 0.0068 & 0.0060 & 0.0020 \\
& EMA & -0.0076 & 0.0060 & 0.3485 & 0.0080 \\
& MAR & 0.0479 & -0.0008 & 0.0020 & 0.0080 & 0.0026 \\
\hline
\end{tabular}

* diagonals: direct contribution of each carcass trait on the variation of dependent price variables, obtained from square of path coefficient.

** off diagonals: joint contribution resulting from correlations between carcass traits and path coefficients of carcass traits.

${ }^{1)} \mathrm{TC}$ : Total contribution of each carcass traits on the variation of dependent price variables, obtained by summing over the direct contribution of a trait and all indirect contributions through correlated carcass traits.

에 표시된 수자는 Table 3 에 제시된 상관계수이다.

다중회귀 모형의 $\mathrm{R}^{2}$ 는 종속변수인 $\mathrm{AP}$ 나 $\mathrm{CP}$ 에서 나타나는 변이 중 독립변량으로 모형에 적합된 $\mathrm{CWT}, \mathrm{BFT}, \mathrm{EMA}, \mathrm{MAR}$ 및 $\mathrm{DP}$ 의 종합적인 영향으로 인해 발생된 부분을 의미한다. 이 $\mathrm{R}^{2}$ 는 경로 계수와 도체 형질들 간의 상관계수를 이용하여 개별 도체형질별로 분할할 수가 있으며 이렇게 도체형질별로 분할된 편 결정계수는 해 당 도체 형질이 종속변량의 변이에 기여하는 크기가 되며 이것을 통해 개별 도체형질들의 상대적 영향력을 좀 더 정확히 평가할 수 있다.

$\mathrm{MAR}$ 이 $\mathrm{AP}$ 의 변이에 미치는 직접효과는 $0.6619(=0.8136 \times$ $0.8136)$ 이고, 4 개의 간접효과는 각각 $-0.0033(=0.8163 \times 0.14$ $\times(-0.0282)), \quad-0.0185(=0.8163 \times 0.22 \times(-0.1056)), \quad 0.0107$ $(=0.8163 \times 0.0107 \times 0.1066) \quad$ 그리고 $\quad 0.0165(=0.8163 \times 0.27$ $\times 0.0754$ 이다. 따라서 $\mathrm{MAR}$ 이 $\mathrm{AP}$ 의 변이에 기여하는 영향력의 크기 즉 상대적 기여도는 $0.6672(=0.6619-0.0033-0.0185$ $+0.0107+0.0165)$ 가 된다. 이와 같은 방법으로 계산한 $\mathrm{AP}$ 와 $\mathrm{CP}$ 의 변이에 미치는 개별 도체형질들의 영향력이 Table 5 에 표시되어 있는데, 본 연구에 변이요인으로 선정된 5 개의 도체 형질 (CWT, $\mathrm{BFT}, \mathrm{EMA}, \mathrm{MAR}$ 및 $\mathrm{DP})$ 중에서는 $\mathrm{MAR}$ 이 $\mathrm{AP}$ 의 변이에 가장 큰 영향력을 보이고 있다. 그리고 $\mathrm{EMA}$ 와 $\mathrm{DP}$ 는 $\mathrm{AP}$ 의 변이에 대 한 상대적 기여도가 각각 0.0232 및 0.0226 으로 MAR의 영향력 (0.6672)에 비해 매우 작았으나 CWT나 BFT의 영향력(각각
-0.0047 과 -0.0097$)$ 보다는 다소 큰 편이었다. $\mathrm{CP}$ 의 변이에 기 여하는 5 개 도체 형질의 상대적 기여도를 보면 MAR이 0.4028 로 제일 컸으며 그 다음이 $\mathrm{CWT}$ 의 0.3965 로 컸던 반면에 $\mathrm{BFT}$ 의 기 여도는 -0.0155 로 5 개의 도체 형질 중에서 제일 작았다. 이상을 종합해 보면 $\mathrm{AP}$ 를 결정하는데는 $\mathrm{MAR}$ 이 그리고 $\mathrm{CP}$ 를 결정하는 데는 MAR과 $\mathrm{CWT}$ 가 중요한 역할을 하는 것으로 판단된다. 일반 적으로 농가의 수익성 측면에서는 $\mathrm{AP}$ 보다는 $\mathrm{CP}$ 가 더 중요한 것 으로 알려지고 있는데 그 이유는 $\mathrm{AP}$ 는 단순히 도체의 질을 결정하 는 판단기준이 되지만 $\mathrm{CP}$ 는 농가의 조수입을 결정하기 때문이다. 본 연구에서 얻어진 CWT와 MAR의 기여도 는 Pyatt (2005) 등 이 보고한 결과와는 다소 차이가 나는 결과였는데 Pyatt (2005)는 $\mathrm{CP}$ 의 변이 중에서 $\mathrm{CWT}$ 에 의해 발생되는 부분이 $51 \%$ 였고, $\mathrm{MAR}$ 이 담당하는 부분이 $10 \%$ 였음을 보고한 바 있다.

본 연구에서 $\mathrm{BFT}$ 가 $\mathrm{CP}$ 의 변이 중에서 담당하는 부분이 매우 작았다. 이것은 연령이 많은 암소에서 등지방두께가 도체의 가격을 결정하는데 중요한 역할을 하지 못함을 의미한다. 그러므로 번식에 이용하던 암소에서는 출하 전 마무리 비육을 하는 과정에서 등지방 두께를 늘리더라도 도체의 가격에는 큰 영향을 미치지 않음을 의미 한다. 그렿더라도 등지방두께의 침착이 식품으로 이용되지 못하는 부분을 생산하고 그 생산단가가 상대적으로 살코기를 생산하는 단 가에 비해 비싸다는 점을 고려해서 피해야만 한다. 


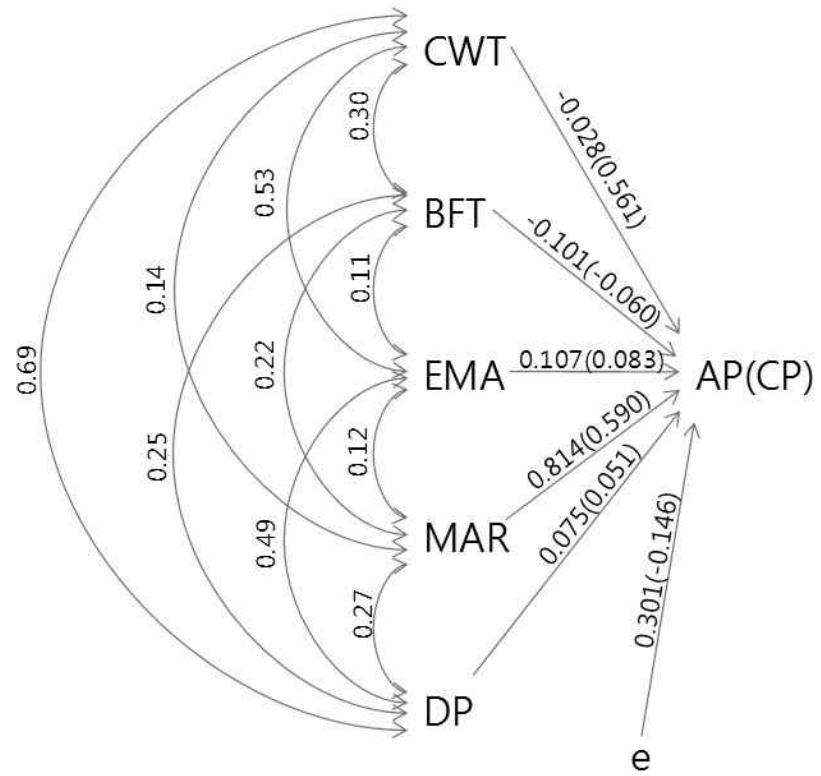

Fig. 1. Path diagram illustrating cause and effect relationships between carcass traits (CWT, BFT, EMA, MAR and DP) and carcass prices (AP or CP). Numbers along single-headed arrows are path coefficients. Numbers along double-headed arrows are path coefficients. Correlation coefficients among traits were calculated using the residual values, listed in table 3 . Path coefficients were standardized partial regression coefficients of carcass traits on carcass value, $\mathrm{AP}(\mathrm{CP})$, listed in table 4

\section{요 약}

본 연구는 성숙한 한우 암소 도체에서 몇 개의 도체형질들이 경 락단가나 도체가격과 같은 가격변수의 변이에 미치는 영향력을 파 악하기 위하여 도체형질과 가격변수들 간의 상관관계 추정, 다중회 귀분석 및 경로분석 등을 실시했다. 자료는 강원도 홍천지역 한우 사육농가에서 번식우로 사용되다 2008년도에 도축된 96두의 도체 판정결과를 이용하였다. 도축된 암소들의 도축시 평균 나이는 약 51 개월 령이었으며, 도살시 생체중, 냉도체중, 등지방두께, 등심면 적, 9단계로 구분하여 평가한 근내지방도 및 도체율의 평균치는 각 각 $556.81 \mathrm{~kg}, 319.24 \mathrm{~kg}, 10.95 \mathrm{~mm}, 78.08 \mathrm{~cm}^{2}, 3.92$ 및 $57.19 \%$ 였다. 그리고 도체경락단가와 도체가격은 각각 12,681 원 및 4,070 천원이었다. 경락단가와 상관계수가 큰 형질은 MAR, DP 및 $\mathrm{EMA}$ 등이었고 육량지수는 상관계수가 제일 작았다.

도체 경락단가를 종속변수로 $\mathrm{CWT}, \mathrm{BFT}, \mathrm{EMA} \mathrm{MAR}$ 및 $\mathrm{DP}$ 등 5 개의 도체 형질을 독립변수로 적합시켜 추정한 다중회귀 방정 식에서 모형 방정식의 결정계수는 $69.86 \%$ 였고, 도체가격을 종속변 수로 하여 추정한 모형 방정식의 결정계수는 $85.43 \%$ 였다. 다중회 귀 분석에서 $\mathrm{CWT}, \mathrm{BFT}, \mathrm{EMA}, \mathrm{MAR}$ 및 $\mathrm{DP}$ 의 표준화 편회귀
계수는 $\mathrm{AP}$ 를 종속변량으로 한 방정식에서 각각 $-0.028,-0.106$, $0.107,0.814,0.075$, 그리고 $\mathrm{CP}$ 를 종속변량으로 하는 방정식에서 는 각각 $0.561,-0.060,0.083,0.590$, 및 0.051 으로 나타나 $\mathrm{AP}$ 의 변이에 큰 영향을 미치는 형질은 $\mathrm{MAR}$ 이었고, $\mathrm{CP}$ 의 변이에 큰 영향을 미치는 형질은 $\mathrm{CWT}$ 와 $\mathrm{MAR}$ 이었던 것으로 판단된다. 경로분석 결과에서도 $\mathrm{AP}$ 의 변이에 큰 영향을 미치는 형질은 $\mathrm{MAR}$ 로서 직접효과와 간접효과를 합친 $\mathrm{MAR}$ 의 기여도는 0.668 이 었다. 그리고 $\mathrm{CP}$ 의 변이에 영향을 미치는 $\mathrm{MAR}$ 의 기여도는 0.408 그리고 $\mathrm{CWT}$ 의 기여도는 0.397 이었다.

이상의 결과를 종합해보면 육량지수는 $\mathrm{AP}$ 나 $\mathrm{CP}$ 에 큰 영향을 미 치지 않으며 $\mathrm{AP}$ 의 변이에 영향을 크게 미치는 것은 $\mathrm{MAR}$ 이고 $\mathrm{CP}$ 에 영향을 크게 미치는 형질은 MAR과 CWT였다.

\section{인 용 문 헌}

김내수, 이중재, 주종철. 2006. MTDFREML 방법과 Gibbs Sampling 방 법에 의한 한우의 육질형질 유전모수 추정. 한국동물자원과학회지 : 48(3) 337-344.

문원곤, 김병우, 노승희, 김효선, 정대진, 선두원, 김경남, 윤영탁, 정진형, 전진태, 이정규. 2007. 한우 도체형질의 환경효과 및 유전모수의 추정. 한국동물자원과학회지 : 49(6) 689-698,

박철진, 박영일. 2002. 한우의 성장형질과 도체형질에 대한 유전상관 추정. 동물자원지 : 44(6) 685-692.

윤호백, 김시동, 나승환, 장은미, 이학교, 전광주, 이득환. 2002. 거세한우의 도체형질에 대한 유전모수 추정. 동물자원지 : 44(4) 383 390

정 준, 이성수, 박노형, 성낙일, 장윤호, 최성호, 송만강, 서형기, 이명일. 2006. 한우 노산암소에 대한 발정억제제 및 항산화제의 급여가 증체와 도체성적에 미치는 영향. 한국동물자원과학회지 : 48(2) 255-268.

정 준, 황정미, 성낙일, 김정배, 황일기, 김용철. 2009. 수용성 지방유화제 첨가가 비육후기 한우거세우의 발육과 도체성적에 미치는 영향. 한국 동물자원과학회지. 51(5):395-406.

축산물판정세부기준. 2007. 농림부고시 제2007-40호. 농림부.2007.6.13

통계청 국가통계포털 http://www.kosis.kr (한육우 시도/성별 마리수)

황정미, 김시동, 최연호, 윤호백, 박철진. 2008. 한우 거세우의 도체형질에 대한 유전모수 추정. 한국동물자원과학회지 : 50(5) 613-620.

Apple, J. K., Davis, J. C., Stephenson, J., Hankis, J. E., Davis, J. R. and Beaty, S. L. 1999. Influence of body condition score on carcass characteristics and subprimal yield from cull beef cows. J. Anim. Sci. 77:2660-2669.

Cranwell, C. D., Unruh, J. A., Brethour, J. R., Simms, D. D. and Campbell, R. E. 1996. Influence of steroid implants and concentrate feeding on performance and carcass. J. Anim. Sci. 74:1770-1776.

Galli, I., Teira, G., Perlo, F., Bonato, P., Tisocco, O., Monje, A. and Vittone, S. 2008. Animal performance and meat quality in cull cows with early weaned calves in Argentina. Meat Science 79 
(2008) 521-528.

Gresham, J. D., Holloway, J. W., Butts, Jr., W. T. and McCurley, J. R. 1986. Prediction of Mature Cow Carcass Composition from Live Animal Measurements. J. Anim. Sci. 63:1041-1048.

Ibi, T., Kahi, A. K. and Hirooka, H. 2006. Effect of carcass price fluctuations on genetic and economic evaluation of carcass traits in Japanese Black cattle. J. Anim. Sci. 84:3204-3211.

Kahi, A. K., Oguni, T., Sumio, Y. and Hirooka, H. 2007. Genetic relationships between growth and carcass traits and profitability in Japanese Brown cattle. J. Anim. Sci. 85:348-355.

Li, C. C. 1977. Path analysis. The Boxwoo Press, Pacific Grove, CA Lynch, M. and Walsh, B. 1998. Genetics and analysis of quantitative traits. Sinauer Associates, Inc., Sunderland, MA.

Oikawa, T., Hoque, M. A., Hitomi, T., Suzuki, K. and Uchida, H. 2006. Genetic parameters for traits in performance and progeny tests and their genetic relationships in Japanese Black cattle. Asian-Aust. J. Anim. Sci. 19:611-616.
Pyatt, N. A., Berger, L. L., Faulkner, D. B., Walker, P. M. and Rodriguez-Zas, S. L 2005. Factors affecting carcass value and profitability in early-weaned Simmental steer: I. Five-year average pricing. J. Anim. Sci. 83:2918-2925.

Rios-Utrera, A., Cundiff, L. V., Gregory, K. E., Koch, R. M., Dikeman, M. E., Koohmaraie, M. and Van Vleck, L. D. 2005. Genetic analysis of carcass traits of steers adjusted to age, weight, or fat thickness slaughter endpoints. J. Anim. Sci. 83:764-776.

Smith, T., Domingue, J. D., Paschal, J. C., Franke, D. E., Bidner, T. D. and Whipple, G. 2007. Genetic parameters for growth and carcass traits of Brahman steers. J. Anim. Sci. 85(6):1377-1384.

Van Vleck, L. D., Cundiff, L. V., Wheeler, T. L., Shackelford, S. D. and Koohmaraie, M. 2007. Across-breed adjustment factors for expected progeny differences for carcass traits. J. Anim. Sci. 85:1369-1376.

(접수일자 : 2010. 1. 8 / 수정일자:2010. 2. 17 / 채택일자 : 2010. 2. 22) 